\title{
Pemetaan Potensi Kekeringan Lahan se-pulau Batam menggunakan Teknik Sistem Infor- masi Geografis (SIG) dan Penginderaan Jauh
}

\author{
Titi Aprilliyanti ${ }^{1}$ dan Muhammad Zainuddin ${ }^{2}$
}

\author{
Program Studi Teknik Geomatika, Politeknik Negeri Batam, Batam Kepulauan Riau, Indonesia ${ }^{12}$ \\ Email Koresponden:titiaprilliyanti19@gmail.com
}

\begin{abstract}
Diterima: 19 Februari 2017/Disetujui: 28 Februari 2017/ Publikasi online: 31 Maret 2017
(c) 2017 Fakultas Geografi UGM dan Ikatan Geograf Indonesia (IGI)
\end{abstract}

\begin{abstract}
Abstrak Kekeringan merupakan hubungan antara ketersediaan air yang jauh dibawah kebutuhan baik untuk kebutuhan hidup, pertanian, kegiatan ekonomi dan lingkungan. Informasi mengenai potensi kekeringan sangat diperlukan untuk pencegahan ataupun penanggulangan untuk mengurangi dampak negatif yang ditimbulkan. Adapun tujuan dari penelitian ini adalah menghasilkan peta potensi kekeringan lahan di Batam yang berbasis web. Dalam penelitian ini memanfaatkan teknik penginderaan jauh dan SIG. Penggunaan citra landsat 8 untuk menentukan nilai LST (Land Surface Temperature) dan penggunaan lahan kemudian di overlay dan dilakukan scoring. Tahap akhir penelitian yaitu melakukan validasi terhadap parameter-parameter yang mempengaruhi dengan mengambil beberapa sampel. Adapun hasil akhir dari penelitian ini adalah peta potensi kekeringan se-pulau Batam yang memiliki 5 kelas potensi kekeringan. Kelas potensi kekeringan sangat rendah dengan luas area 2629.45 ha yang dominan terletak pada Kecamatan Sungai Beduk, Sekupang dan Batu Aji. Kelas potensi kekeringan rendah dengan luas area 9585.521 ha yang dominan terletak pada Kecamatan Sekupang. Kelas potensi kekeringan sedang dengan luas area 9507.12 ha yang dominan terletak pada Kecamatan Sekupang. Kelas potensi kekeringan tinggi dengan luas area 7081.392 ha yang dominan terletak pada Kecamatan Sekupang, Sagulung dan Nongsa. Kelas potensi kekeringan sangat tinggi dengan luas area 15600.12 ha yang dominan terletak pada Kecamatan Batam Kota dan Nongsa.
\end{abstract}

Kata kunci: Kekeringan lahan, Penggunaan lahan, LST, Potensi kekeringan

\begin{abstract}
Drought is the relationship between the availability of water is far below the need both for the necessities of life, agriculture, economic activities and the environment. Information about potential droughts is indispensable for the prevention or mitigation to reduce the negative impact caused. As for the purpose of this research is to produce a map of potential drought land in the Batam-based web. In this research utilising remote sensing and GIS techniques. The use of landsat 8 to determine the value of the LST (Land Surface Temperature) and land use overlay and then done the scoring. The final stage of research i.e. performs validation against parameters that influence by taking some samples. As for the end result of this research is to map the potential dryness in Island Batam which have 5 classes of potential drought. The class of potential drought is very low with an area of 2629.45 ha, the dominant River is located in Sungai Beduk, Sekupang and Batu Aji. The class of potential low drought with an area of 9,585,521 ha located on the dominant Sub Sekupang. The class of potential drought being with an area of 9507.12 ha located on the dominant Sub Sekupang. The class of potential high dryness with an area of 7,081,392 ha located on the dominant Sub Sekupang, Sagulung and Nongsa. The class of potential drought is extremely high with an area of 15600.12 ha located on the dominant sub Batam city and Nongsa.
\end{abstract}

Keywords: Dryness of land, land use, LST, Dryness potential

\section{PENDAHULUAN}

Kekeringan adalah suatu kejadian yang dapat mengancam dan mengganggu berlangsungnya hidup manusia. Kekeringan berkaitan erat dengan cadangan air yang ada di dalam tanah, baik cadangan air untuk lahan maupun untuk kebutuhan manusia sehari-hari. Di bidang pertanian, kekeringan membawa dampak yang cukup signifikan. Kekeringan dapat menjadi penghambat produksi padi yang akan berdampak pada kondisi ekonomi daerah setempat (Irianto, 2002).

Kekeringan menurut (Parwata et al., 2014) adalah hubungan antara ketersediaan air dibawah rata-rata minimal kebutuhan air untuk hidup, lingkungan maupun kegiatan ekonomi. Kekeringan dapat dibedakan menjadi beberapa jenis yaitu, kekeringan meteorologi adalah kekeringan yang pendekatan analisisnya menggunakan curah hujan atau keadaan cuaca. Yang kedua kekeringan geologi adalah kekeringan yang pendekatan analisisnya menggunakan bentuk lahan (Parwata et al., 2014).

Menurut (Jamil, 2013) kekeringan dapat dikeompokkan menjadi beberapa jenis sebagai berikut: kekeringan hidrologi, kekeringan meteorologis, kekeringan pertanian, dan kekeringan sosial ekonomi. Kekeringan dapat disebabkan karena curah hujan dibawah normal dalam jangka waktu yang cukup lama sehingga menyebabkan turun nya elevasi permukaan laut, sedangkan di bidang pertanian bisa disebabkan karena tidak ada kandungan air di dalam tanah sehingga tidak dapat di tanam dengan tumbuhan. 
Kekeringan menjadi dampak yang sangat serius apabila sudah mempengaruhi perekonomian pada suatu daerah (Adiwicaksono et al., 2014).

Dilihat dari akibat kekeringan yang terlihat, maka perlu dilakukan penanggulangan untuk mengurangi dampak yang ditimbulkan. Akan tetapi informasi mengenai kekeringan lahan masih kurang untuk saat ini. Padahal informasi tersebut sangat dibutuhkan oleh berbagai pihak. Informasi kekeringan lahan dapat membantu masyarakat sekitar untuk mengetahui potensi kekeringan pada daerahnya, sehingga masyarakat dapat melakukan tindakan yang dapat meminimalkan dampak kekeringan tersebut. Karena bisa jadi kekeringan terjadi karena kebiasaan buruk yang dilakukan oleh masyarakat. Sedangkan untuk pemerintah, informasi ini bisa dijadikan sebagai acuan untuk pengambilan tindakan untuk menghindari atau mengurangi dampak kekeringan tersebut (Raharjo 2011). Penyebab kekeringan lahan juga bisa disebabkan karena daerah yang dahulunya merupakan daerah vegetasi menjadi wilayah pemukiman (Adiningsih, 2014).

Transformasi citra banyak digunakan untuk pengolahan citra satelit, misalnya transformasi tasseled cap yang memanfaatkan feature space tiga saluran yang menghasilkan sumbu kecerahan (brightness), kehijauan (greenness), kelayuan (yellowness), dan ketidak tentuan (noneesuch). Modifikasi tasseled cap untuk 6 saluran pada Landsat TM, yaitu saluran 1-5, dan 7 (Murdiyati et al., 2016). Hasilnya adalah indeks kecerahan (brightness index), indeks kebasahan (wetness index), dan indeks kehijauan (greeness index). Salah satu indeks vegetasi adalah normalized difference vegetation index (NDVI) yang merupakan kombinasi antara teknik penisbahan dengan teknik pengurangan citra (Maru dan Hidayati, 2016).

Menurut Raharjo (2009) telah meneliti tentang aplikasi penginderaan jauh dan sistem informasi geografis (SIG) untuk mengidentifikasi potensi kekeringan di kabupaten Kebumen dengan menggunakan indeks kecerahan, indeks kebasahan serta indeks vegetasi.

Berdasarkan permasalahan yang telah dijabarkan di atas, maka dilakukan penelitian yang berjudul Pemetaan Potensi Kekeringan Lahan Se-Pulau Batam Menggunakan Teknik Sistem Informasi Geografis (SIG) Dan Penginderaan Jauh Berbasis Web" dengan teknik penginderaan jauh menggunakan citra satelit landsat 8 perekaman bulan April 2016 untuk melihat potensi kekeringan pada bulan tersebut. Variabel yang digunakan adalah indeks vegetasi (NDVI) dan LST (Land Surface Temperature) serta parameter berupa peta penggunaan lahan, peta klasifikasi tanah, data suhu permukaan lahan dan data curah hujan (Markham et al., 2014). Diharapkan hasil penelitian ini mampu menambah informasi bagi masyarakat umum dan sebagai dasar pertimbangan pengambilan keputusan bagi pemerintahan.
Adapun tujuan dari penelitian ini adalah mengetahui pemetaan persebaran kekeringan lahan se-pulau Batam menggunakan penggunaan lahan dan nilai LST (Land Surface Temperature).

\section{METODE PENELITIAN}

Data pada penelitian ini adalah data penginderaan jauh berupa Citra Landsat 8 perekaman 16 April 2016 yang didapatkan dengan mengunduh langsung melalui situs www.earthexplorer.usgs.gov.

Tahapan melakukan proses pengolahan citra digital adalah melakukan cropping, koreksi radiometrik, geometrik, komposit dan transformasi citra menggunakan software ENVI 4.6. Sedangkan pengolahan parameter dilakukan dengan scoring dan layout dengan menggunakan software ArcGis 10 yang menghasilkan peta potensi kekeringan lahan se-pulau Batam. Diagram alir penelitian dapat dilihat pada Gambar 1.

\section{HASIL DAN PEMBAHASAN}

Peta potensi kekeringan lahan merupakan peta yang berasal dari pengolahan data/parameter yang berpengaruh terhadap kekeringan lahan. Parameter yang digunakan dalam pengolahan peta potensi kekeringan yaitu penggunaan yaitu peta penggunaan lahan dan peta suhu permukaan/LST (Land Surface) (Kempe, 2013). Pemberian bobot/scoring pada setiap parameter berbeda-beda. Berdasarkan bobot dari parameter-parameter yang mempengaruhi kekeringan, maka didapatkan pembagian kelas untuk potensi kekeringan lahan seperti yang terlihat pada Tabel 1.

Klasifikasi dibagi menjadi 5 kelas yaitu potensi kekeringan sangat rendah, potensi kekeringan rendah, potensi kekeringan sedang, potensi kekeringan tinggi dan potensi kekeringan sangat tinggi. Adapun luas wilayah pada masing-masing kelas yaitu dengan luas wilayah tertinggi yaitu pada kelas potensi kekeringan, hal ini seperti penelitian yang pernah dilakukan oleh (Hadi et al., 2016).

Berdasarkan Tabel 1 dapat dilihat persentase dari masing-masing kelas potensi kekeringan lahan. Persentase kelas potensi kekeringan lahan adalah sebagai berikut:

1.Kelas potensi kekeringan sangat rendah memiliki luas area sebesar 2629.45 ha dengan lokasi dominan di kecamatan Sungai Beduk, Sekupang dan Batu Aji.

2.Kelas potensi kekeringan rendah memiliki luas area sebesar 9585.521 ha dengan lokasi dominan di kecamatan Sekupang.

3.Kelas potensi kekeringan sedang memiliki luas area sebesar 9507.12 ha dengan lokasi dominan di kecamatan Kecamatan Sekupang.

4.Kelas potensi kekeringan tinggi memiliki luas area sebesar 7081.392 ha dengan lokasi dominan di kecamatan Kecamatan Sekupang, Sagulung dan Nongsa.

5.Kelas potensi kekeringan sangat tinggi memiliki luas 


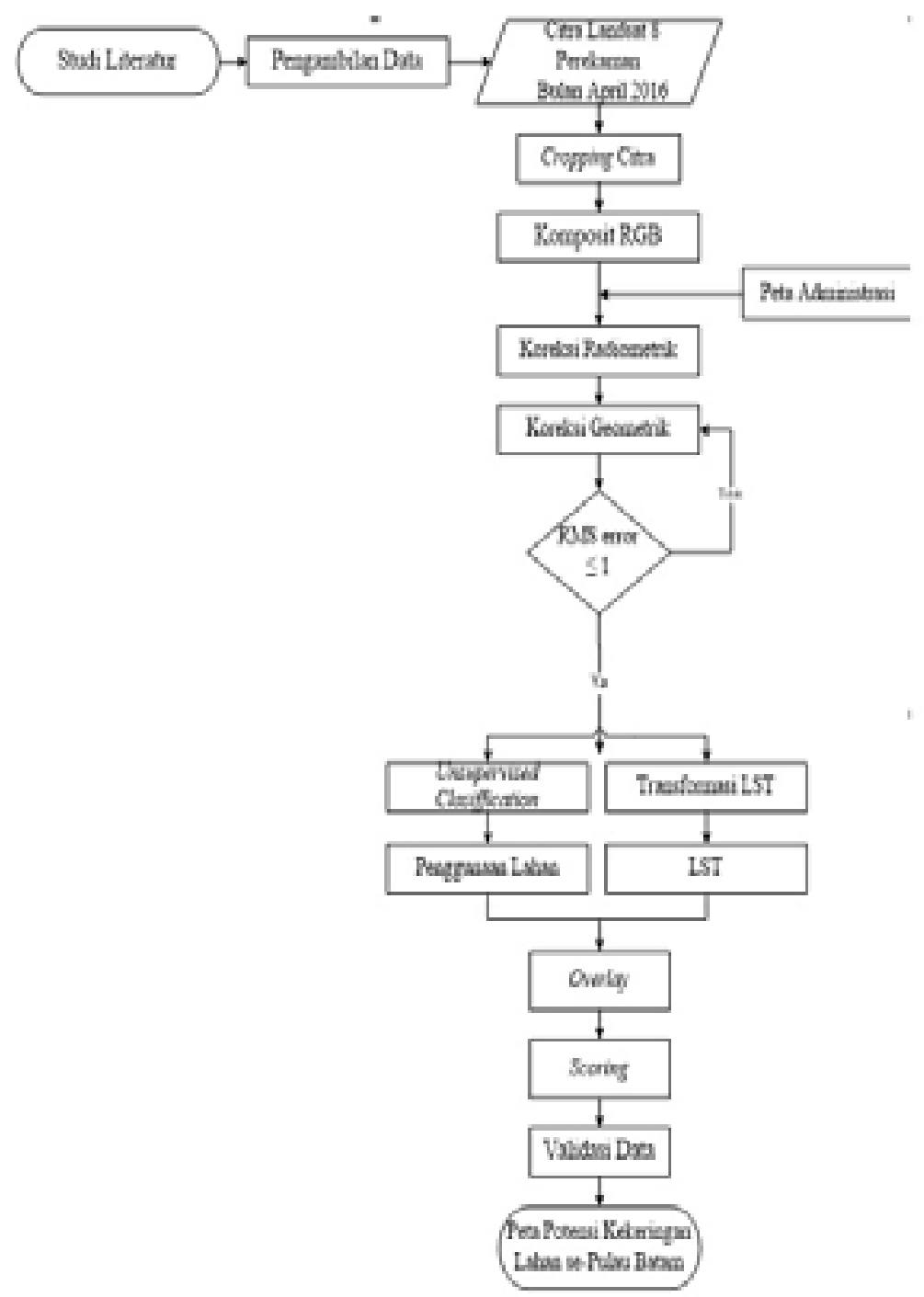

Gambar 1. Diagram Alir Penelitian

area sebesar 15600.12 ha dengan lokasi dominan di kecamatan Batam Kota dan Nongsa.

6.Area kelas potensi yang paling besar yaitu kelas potensi kekeringan sangat tinggi dengan luas area sebesar $15600.12 \mathrm{ha}$, sedangkan area kelas paling kecil yaitu kelas potensi kekeringan sangat rendah dengan luas area sebesar 2629.45 ha.

Gambar 2. Persentase Luas Kelas Potensi Kekeringan Lahan se-Pulau Batam

\section{Graflk Luas Kawasan Poteasi Kekeringan} Lahan Pulan Batam

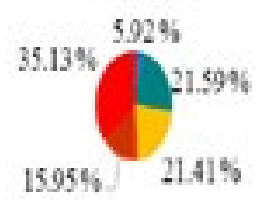

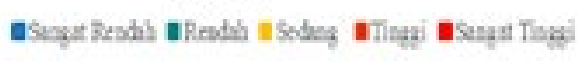

Pada Gambar 2 merupakan persentase dari masing-masing kelas potensi kekeringan lahan sepulau Batam. Berdasarkan scoring penggunaan lahan dan LST (Land Surface Temperature) dihasilkan peta potensi kekeringan lahan yang terdiri dari 5 kelas dengan luas yang dapat dilihat pada Tabel 1, sehingga diperoleh persentasi kelas potensi kekeringan sangat tinggi sebesar $35.13 \%$, kelas potensi kekeringan tinggi sebesar $15.95 \%$, kelas potensi kekeringan sedang sebesar $21.41 \%$, kelas potensi kekeringan rendah sebesar $21.59 \%$ dan kelas potensi kekeringan sangat rendah sebesar $5.92 \%$ dan tergolong kelas yang memiliki persentase paling kecil.

Gambar 3 merupakan peta kekeringan lahan pulau Batam 2016. Peta tersebut memiliki 5 kelas dengan luas yang berbeda-beda. Secara umum pulau Batam. Dari hasil yang diperoleh menunjukkan potensi kekeringan sangat tinggi yang ditandai dengan warna merah, yang menunjukkan potensi kekeringan lahan hampir sama dengan penelitian sebelumnya (Wibowo dan Satria, 2016) yang dilakukan di Natuna, Kepulauan Riau. 
Tabel 1. Klasifikasi Potensi Kekeringan Lahan

\begin{tabular}{llll}
\hline Peta & Klasifikasi & Bobot & Luas (Ha) \\
\hline $\begin{array}{l}\text { Potensi Kekeringan } \\
\text { Lahan }\end{array}$ & $\begin{array}{l}\text { Potensi Kekeringan Sangat } \\
\text { Rendah }\end{array}$ & $30-40$ & 2629.45 \\
& $\begin{array}{l}\text { Potensi Kekeringan Rendah } \\
\text { Potensi Kekeringan Sedang }\end{array}$ & & $51-51$ \\
& & 9585.521 \\
& Potensi Kekeringan Tinggi & $63-73$ & 7081.392 \\
& $\begin{array}{l}\text { Potensi Kekeringan Sangat } \\
\text { Tinggi }\end{array}$ & $74-84$ & 15600.12 \\
& & & \\
\hline
\end{tabular}
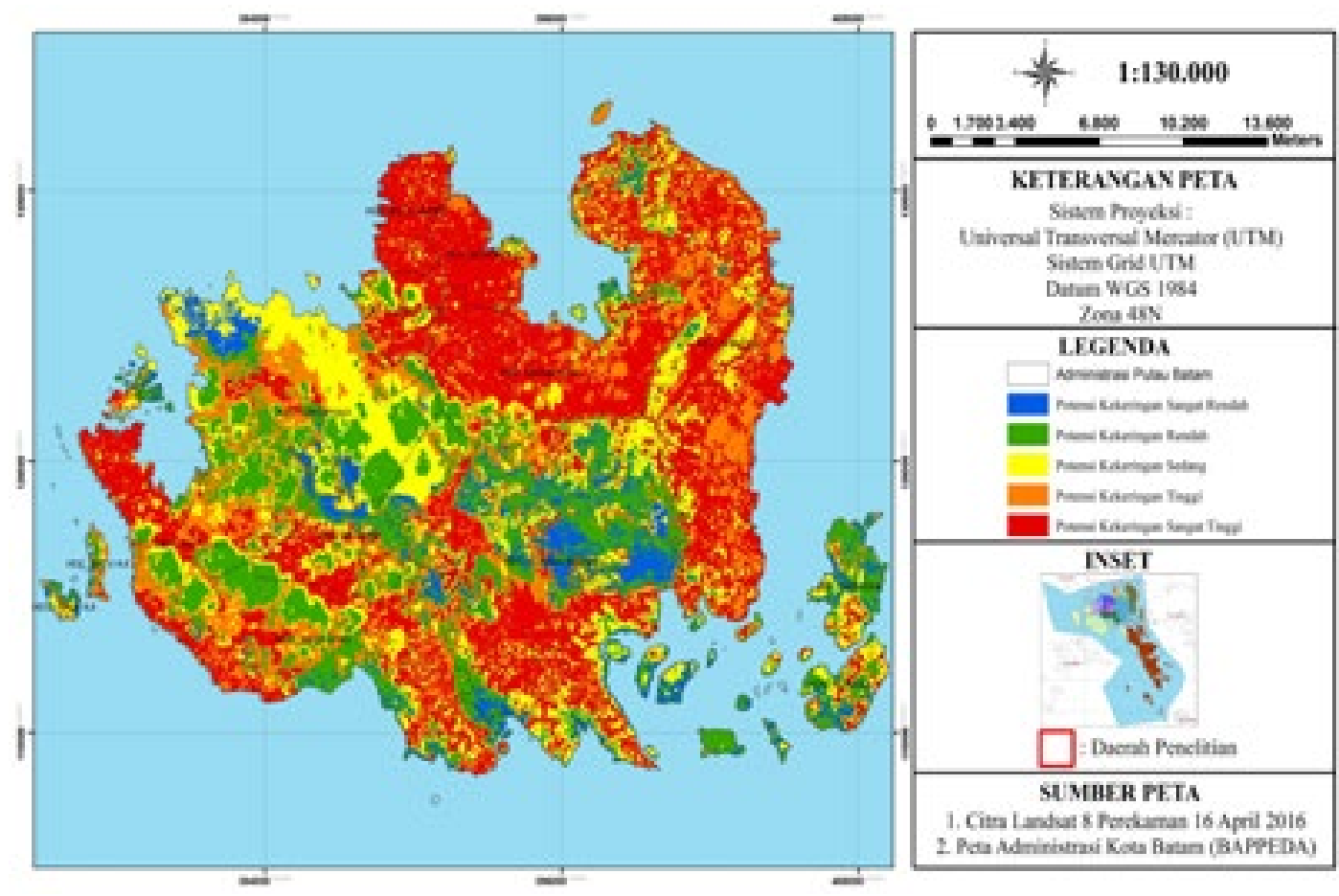

Gambar 3. Peta Potensi Kekeringan Lahan Pulau Batam (Aprilliyanti, 2017)

\section{KESIMPULAN}

Berdasarkan hasil penelitian yang telah dilakukan, maka dapat disimpulkan bahwa persebaran potensi kekeringan lahan pulau Batam telah dapat diketahui dari pengolahan penggunaan lahan dan nilai suhu permukaan/LST (Land Surface Temperature) dengan metode overlay dan scoring/pembobotan. Hasil scoring dari peta penggunaan lahan dan peta suhu permukaan lahan/LST (Land Surface Temperature) dapat menghasilkan peta potensi kekeringan lahan se-pulau Batam sebagai output dari penelitian ini. Berdasarkan hasil overlay peta penggunaan lahan dan peta suhu permukaan/LST (Land Surface Temperature) diketahui bahwa batam memiliki potensi kekeringan lahan yang sangat tinggi dengan luas area sebesar 15600.12 ha atau sebanyak 33.13 \%.Pemetaan potensi kekeringan lahan se-pulau Batam disajikan dalam bentuk web supaya lebih mudah diakses dan informatif.

\section{DAFTAR PUSTAKA}

Adiningsih, E. S. (2014). Tinjauan metode deteksi parameter kekeringan berbasis data penginderaan jauh. Jakarta: Pusat Teknologi dan Data Penginderaan Jauh, Lembaga Penerbangan dan Antariksa Naional.

Adiwicaksono, H., Sudarto, S., \& Widianto, W. (2014). Estimasi Distribusi Spasial Kekeringan Lahan Di Kabupaten Tuban Menggunakan Penginderaan Jauh Dan Sistem Informasi Geografis. Jurnal Tanah dan Sumberdaya Lahan, 1(2), 70-76.

Hadi, A. P., Danoedoro, P., \& Sudaryatno, S. (2016). Penentuan tingkat kekeringan lahan berbasis analisa citra aster dan sistem informasi geografis. Majalah Geografi Indonesia, 26(1), 1-26.

Irianto, G. (2002). Menyoal Alih Fungsi Lahan, Kekeringan, dan Ketahanan Pangan.

Jamil, D. H. (2013). Deteksi Potensi Kekeringan 
Berbasis Penginderaan Jauh Dan Sistem Informasi Geografis Di Kabupaten Klaten. Geo-image, 2(2).

Kempe, C. H. (2013). Sexual abuse, another hidden pediatric problem: the 1977 C. Anderson Aldrich lecture. In C. Henry Kempe: A 50 Year Legacy to the Field of Child Abuse and Neglect (pp. 179-192). Springer Netherlands.

Maru, A. C. H., \& Hidayati, I. N. (2016). Pemanfaatan Citra Quickbird Dan Sig Untuk Pemetaan Tingkat Kenyamanan Permukiman Di Kecamatan Semarang Barat Dan Kecamatan Semarang Utara. Majalah Geografi Indonesia, 30(1), 1-8.

Murdiyati, S. R., Danoedoro, P., \& Jatmiko, R. H. (2016). Integrasi Transformasi Spektral Citra Landsat Etm+ Dan Sig Untuk Pemetaan Pola Rotasi Tanam Lahan Sawah Kabupaten Dan Kota Semarang Serta Daerah Sekitarnya Di Jawa Tengah. Majalah Geografi Indonesia, 24(2), 121-141.

Parwata, I. G. M. A., Indradewa, D., Yudono, P., Kertonegoro, B. D., \& Kusmarwiyah, R. (2014).
Respon Pertumbuhan dan Hasil Tanaman Jarak Pagar (Jatropha curcas L.) terhadap Cekaman Kekeringan di Lahan Pasir Pantai pada Tahun Pertama Siklus Produksi. Jurnal Agronomi Indonesia (Indonesian Journal of Agronomy), 42(1).

Raharjo, P. D. (2011). Teknik Penginderaan Jauh dan Sistem Informasi Geografis untuk Identifikasi Potensi Kekeringan. MAKARA of Technology Series, 14(2).

Raharjo, P. D. (2011). Teknik Penginderaan Jauh dan Sistem Informasi Geografis untuk Identifikasi Potensi Kekeringan. MAKARA of Technology Series, 14(2).

Wibowo, A., \& Satria, A. (2016). Strategi Adaptasi Nelayan di Pulau-Pulau Kecil terhadap Dampak Perubahan Iklim (Kasus: Desa Pulau Panjang, Kecamatan Subi, Kabupaten Natuna, Kepulauan Riau). Sodality:: Jurnal Sosiologi Pedesaan, 3(2). 